\title{
Effect of regrowth interval and a microbial inoculant on the fermentation profile and dry matter recovery of guinea grass silages
}

\author{
E. M. Santos, ${ }^{*}$ O. G. Pereira,$\dagger^{1}$ R. Garcia, $†$ C. L. L. F. Ferreira, $\ddagger$ J. S. Oliveira, ${ }^{*}$ and T. C. Silva \\ *Department of Animal Science, Federal University of Paraiba, Areia, 58397000, Brazil \\ †Department of Animal Science, and \\ łDepartment of Food Technology, Federal University of Viçosa, Viçosa, 36570000, Brazil
}

\section{ABSTRACT}

The objectives of this study were to characterize and quantify the microbial populations in guinea grass (Panicum maximum Jacq. cultivar Mombasa) harvested at different regrowth intervals $(35,45,55$, and 65 d). The chemical composition and fermentation profile of silages (after $60 \mathrm{~d}$ ) with or without the addition of a microbial inoculant were also analyzed. Before ensiling, samples of the plants were used for the isolation and identification of lactic acid bacteria (LAB) in the epiphytic microbiota. A $4 \times 2$ factorial arrangement of treatments (4 regrowth intervals $\times$ with/without inoculant) was used in a completely randomized design with 3 replications. Based on the morphological and biochemical characteristics and the carbohydrate fermentation profile, Lactobacillus plantarum was found to be the predominant specie of LAB in guinea grass forage. Linear increases were detected in the dry matter (DM) content and concentrations of neutral detergent fiber, acid detergent fiber, acid detergent insoluble nitrogen, and DM recovery as well as linear reductions in the concentrations of crude protein and $\mathrm{NH}_{3}-\mathrm{N}$ with regrowth interval. Additionally, linear reductions for gas and effluent losses in silages were detected with increasing regrowth interval. These results demonstrate that guinea grass plants harvested after $55 \mathrm{~d}$ of regrowth contain a LAB population sufficiently large to ensure good fermentation and increase the DM recovery. The use of microbial inoculant further enhanced the fermentation of guinea grass at all stages of regrowth by improving the DM recovery.

Key words: ammonia, lactic acid bacteria, tropical grass, crude protein

Received October 21, 2013.

Accepted March 15, 2014.

${ }^{1}$ Corresponding author: odilon@ufv.br

\section{INTRODUCTION}

The use of conserved forage, mainly in the form of silage, is an alternative supply of high-quality forage during periods of feed shortage in Brazil. Among the tropical forage grasses, elephant grass is one of the most promising potential species for silage due to its satisfactory soluble carbohydrate content for ensiling (Zanine et al., 2010) and good palatability (Jobim et al., 2006; Silva et al., 2006). Some studies conducted in Brazil have demonstrated the possibility of ensiling other grasses, such as those of the Cynodon (Evangelista et al., 2000), Panicum (Paziani et al., 2006), and Brachiaria genera (Ribeiro et al., 2008; Santos et al., 2011).

Guinea grass (Panicum maximum Jacq.) originated from tropical Africa, and is suitable for pasture, cut and carry, silage, and hay (FAO, 2009). This grass has good nutritional value, including $\mathrm{CP}$ content ranging from 5.5 to $20.5 \%$ of DM (Aganga and Tshwenyane, 2004) and in vitro DM digestibility of around $66 \%$ (Santos et al., 2008). Research was conducted with dairy cows in Brazil and showed that guinea grass pastures can allow Holstein cows to produce on average $14.0 \mathrm{~kg}$ of milk per day (Hack et al., 2007) and $10.5 \mathrm{~kg} / \mathrm{d}$, as observed by Lima et al. (2006).

The silages of these grasses have the advantage of high annual production per area, perennial growth, a lower risk of loss (considering the aerobic deterioration), and greater range to be harvested when some additives are used (Zanine et al., 2010; Santos et al., 2011). Unfavorable aspects of these grasses include a low water-soluble carbohydrate content (needed for proper fermentation), low DM content at the time of cutting, a high buffering capacity, and a lower energy content compared with corn or sorghum (Santos et al., 2013).

The most commonly used parameters for assessing the fermentation quality of ensiled material are the concentrations of organic acids (lactic, acetic, and butyric acid), $\mathrm{NH}_{3}-\mathrm{N}$ content, and $\mathrm{pH}$. The appropriate content of DM before ensiling is important for good fermentation in the silo (Ashbell and Weinberg, 2003) 
to avoid undesirable fermentations (e.g., by Clostridia). Moreover, NPN and CP concentrations and in vitro digestibility decrease with plant maturity (Snyman and Joubert, 1996).

The use of microbial inoculants has emerged as an alternative approach to promoting good silage fermentations. The main objectives for the use of inoculants in tropical grass silages are to minimize the development of bacteria of the Clostridium genus and improve the nutritional value of the silage (Driehuis et al., 2000), and they also have been used to improve aerobic stability (Schmidt and Kung, 2010). Inoculants allow the use of grasses cut at younger ages, which have high nutritional value. Inoculants have also improved the fermentation of mature grasses (Penteado et al., 2007; Santos et al., 2008). Most research involving the use of microbial inoculants has been conducted in North America and Europe. Studies involving tropical conditions remain scarce, although interest in these products in this region has grown significantly in recent years.

Due to a limited amount of information on the microbial populations in tropical grasses and their silages, the present study was aimed at characterizing and quantifying the microbial populations in guinea grass harvested at different regrowth intervals. The chemical composition, fermentation profile and recovery of matter from these silages in the presence or absence of microbial inoculant were also analyzed.

\section{MATERIALS AND METHODS}

\section{Location and Forage}

The experiment was performed between December 2004 and March 2005 at the Animal Science Department at the Federal University of Viçosa (Viçosa, Minas Gerais, Brazil). Viçosa is located at $20^{\circ} 45^{\prime} \mathrm{S}$ and $42^{\circ} 51^{\prime} \mathrm{W}$ at an altitude of $657 \mathrm{~m}$. The area receives an average annual rainfall of $1,341 \mathrm{~mm}$, approximately $86 \%$ of which occurs between October and March. The local soil is classified as clay loam texture Red-Yellow Argisol.

On November 2, 2004, $500 \mathrm{~kg} /$ ha of dolomitic limestone in the form of dolomitic limestone $(83 \%$ total neutralizing power) was applied to adjust the soil acidity, with the objective of raising the base saturation to $60 \%$. On November 17, the broadcast seeding of guinea grass (Panicum maximum Jacq. 'Mombasa') was performed in an area of approximately 0.3 ha using an application of $100 \mathrm{~kg} / \mathrm{ha}$ of $\mathrm{P}_{2} \mathrm{O}_{5}$ in the form of single superphosphate. Topdressing fertilization using $250 \mathrm{~kg} / \mathrm{ha}$ of a 20-0-20 formula (Fertilizantes Heringer, Manhuaçu, Minas Gerais, Brazil) was applied $30 \mathrm{~d}$ after planting.

\section{Experimental Treatments and Silage Preparation}

The pasture used for this study was randomly divided into 4 plots of $30 \mathrm{~m}^{2}$ to define 4 regrowth intervals of $35,45,55$, and $65 \mathrm{~d}$. To obtain these intervals, the first plot was mowed for height standardization on February 18, 2005. The remaining plots were mowed at 10-d intervals, from the highest to lowest regrowth interval, to collect and to ensile grasses of all regrowth intervals at the same day. When the mowing for height standardization was completed, the plots were immediately fertilized with $250 \mathrm{~kg} /$ ha of a $20-0-20$ formula.

On the day of the treatment, grass was harvested from the 4 plots representing 4 regrowth intervals of $35,45,55$, and $65 \mathrm{~d}$. Grasses were cut at $10 \mathrm{~cm}$ above the soil in all plots using a backpack mower, and were chopped in a stationary forage chopper (model PN Plus 2000; Nogueira S.A., São João da Boa Vista, Brazil) to approximately 1 to $2 \mathrm{~cm}$ of forage particle length. Harvested, chopped forages were either untreated or treated with a microbial inoculant (Sil All C4 comprising Enterococcus faecium, Pediococcus acidilactici, and Lactobacillus plantarum; Alltech, Araucária, Brazil), applied to achieve a final application rate of 100,000 cfu of lactic acid bacteria (LAB)/g of fresh forage. The inoculant was added to chopped forage with a hand sprayer while constantly mixing. Chopped material was ensiled in 15 -L plastic buckets to obtain a packing density of $550 \mathrm{~kg} / \mathrm{dm}^{3}$. Three replicated buckets were prepared for each combination of treatment of regrowth and inoculation. Bucket lids were equipped with a Bunsen valve to allow for gas to escape. The bottoms of the buckets were lined with $3 \mathrm{~kg}$ of sand separated by cotton fabric to capture effluent. All buckets were ensiled in a barn with ambient temperature ranging from 22 to $28^{\circ} \mathrm{C}$ for $60 \mathrm{~d}$.

\section{Sampling and Analytical Procedures}

Microbial Analyses. The isolation of lactobacilli predominant in the grass before harvest was done according to procedures described by Santos et al. (2011). Ten samples were randomly collected from each plot, and a composite sample was formed for immediate microbiological analyses. The identification of isolates from guinea grass was performed using the API 50 $\mathrm{CH}$ carbohydrate fermentation test kit (bioMérieux Inc., Marcy l'Étoile, France). The identification was confirmed using API software (bioMérieux Inc.), which expresses the result as a percentage of identification.

Growth tests were performed in tryptic soy broth (TSB; Difco, São Paulo, SP, Brazil) with salt concentrations of 4.0 and $6.5 \% \mathrm{NaCl}$ and $\mathrm{pH}$ of 7.2 and 9.6. The TSB cultures at $\mathrm{pH} 7.2$ did not have additional 
$\mathrm{NaCl}$ in the media; TSB cultures at $\mathrm{pH} 9.6$ were tested at the 2 different concentrations of $\mathrm{NaCl}$. The isolates were also incubated in de Man, Rogosa, and Sharpe (MRS) broth at $15^{\circ} \mathrm{C}$ and $45^{\circ} \mathrm{C}$. After $24 \mathrm{~h}$ of incubation, the presence of culture growth under the test conditions was indicated by the development of turbidity in the media.

The microbial populations of fresh forages and silages for each treatment were also determined by using 10 $\mathrm{g}$ of a composite sample of silage from the 3 silos in each treatment and adding $90 \mathrm{~mL}$ of phosphate buffer solution to obtain a 10:1 dilution. Serial dilutions were then performed to obtain dilutions ranging from 10:1 to 10:9. Pour plates were prepared with Rogosa agar (Difco) for enumerating LAB, violet red bile agar (Difco) for Enterobacteriaceae and potato dextrose agar (Difco) for yeasts and molds (acidified with $10 \%$ tartaric acid solution). Plates were incubated aerobically at $35^{\circ} \mathrm{C}$ for 48 to $72 \mathrm{~h}$ before counting, except for the yeast and mold plates that were incubated at ambient temperature (ranging from 24 to $27^{\circ} \mathrm{C}$ ) to $5 \mathrm{~d}$. Plates with counts between 30 and 300 colonies were included in the data collection.

General Chemical Analyses. After 60 d of ensiling, the final weights of the silos were recorded and each silo was opened and the silage mixed thoroughly. Silage samples were collected for $\mathrm{pH}$ and ammonia nitrogen determinations according to Bolsen et al. (1992). For $\mathrm{pH}, 25 \mathrm{~g}$ of silage was collected from each silo and after that was combined with $100 \mathrm{~mL}$ of water and was allowed to stand for $1 \mathrm{~h}$ before the $\mathrm{pH}$ reading. Another $25 \mathrm{~g}$ of silage sample was combined with $200 \mathrm{~mL}$ of an $\mathrm{H}_{2} \mathrm{SO}_{4}$ solution and incubated in a refrigerator for $48 \mathrm{~h}$. The mixture was filtered using Whatman 54 filter paper (Whatman Inc., Clifton, NJ), and the filtrate was frozen for subsequent determination of the ammonia nitrogen content.

A hydraulic press was used to compress a 500-g sample of silage for liquid extraction for the determination of the organic acid contents. The extract was treated with $10 \%$ metaphosphoric acid and frozen for later analysis of the lactic, acetic, and butyric acid contents by gas chromatography (AOAC, 1980).

Approximately $500 \mathrm{~g}$ of sample from each silo and from plants before ensiling were predried in a forcedventilation oven at $60^{\circ} \mathrm{C}$ for $72 \mathrm{~h}$. The following properties were determined in these samples: DM content; water-soluble carbohydrate (WSC) concentration according to Deriaz (1961); CP concentration, using the Kjeldahl method; ADIN as described by Licitra et al. (1996); and NDF and ADF concentrations. Neutral detergent fiber and ADF concentrations were evaluated using the compositions of detergent recommended by Mertens (2002) and Goering and Van Soest (1975), respectively. Microextraction in an autoclave was used to quantify the NDF and ADF concentrations (Pell and Schofield, 1993). In the NDF analysis, the samples were treated with thermostable $\alpha$-amylase, without the use of sodium sulfite. Dry matter losses from the silage via the gas and effluent were determined based on the differences between weights according to Jobim et al. (2007).

Statistical Analysis. All microbial data were logarithmically transformed and are presented on a wetweight basis. Chemical data are presented on a DM basis.

Data were analyzed as a $4 \times 2$ factorial arrangement, with factors including 4 regrowth intervals $(35,45,55$, and 65) and 2 treatments (with or without inoculant) in a complete randomized design. Each bucket was considered the experimental unit. Data were analyzed using the model

$$
Y_{i j k}=\mu+R I_{i}+I_{j}+(R I \times I)_{i j}+e_{i j k},
$$

where $\mathrm{Y}_{\mathrm{ijk}}=$ dependent variable representing the response for the regrowth interval i observed in inoculant $\mathrm{j}, \mu=$ mean, $\mathrm{RI}_{\mathrm{i}}=$ regrowth interval effect, $\mathrm{I}_{\mathrm{j}}=$ inoculant effect, $(\mathrm{RI} \times \mathrm{I})_{\mathrm{ij}}=$ interaction effect, and $\mathrm{e}_{\mathrm{ijk}}=$ residual error.

Data were examined by analyses of variance and regression using the software Sistema para Análises Estatísticas (SAEG; version 8.0; Universidade Federal de Viçosa, 1999) and differences were reported as significant when $P<0.05$. The effects of the inoculant at the different regrowth intervals were separated by the Tukey test $(P \leq 0.05$; Snedecor and Cochran, 1980).

The effects of the regrowth interval were evaluated by simple linear regression analysis using the determination coefficients and significance of regression parameters as model choice criteria. These parameters were tested using the $t$-test at a probability level of $5 \%$. For evaluating the $\mathrm{pH}$, according to the fermentation period, it was done an adjustment of the data to the nonlinear model $\mathrm{Yt}=\mathrm{A}+\mathrm{B} \times \mathrm{e}^{-\mathrm{ct}}[$ where $\mathrm{A}=$ final $\mathrm{pH}, \mathrm{B}=$ decrease in $\mathrm{pH}$ with the fermentation period (t) tending to the infinite, and $\mathrm{c}=$ rate of decline of $\mathrm{B}$ ], proposed by Hristov and McAllister (2002).

\section{RESULTS AND DISCUSSION}

The microbial and chemical compositions of guinea grass at different regrowth intervals before ensiling are presented in Table 1 . The LAB populations ranged from $4.35(35 \mathrm{~d})$ to $5.55(65 \mathrm{~d}) \log \mathrm{cfu} / \mathrm{g}$. Meeske et al. (1999) reported a population of approximately 1 $\log \mathrm{cfu} / \mathrm{g}$ in fresh forage of Digitaria eriantha. In an analysis of the indigenous microflora of guinea grass 
Table 1. Microbial populations, DM, CP, $\mathrm{NH}_{3}-\mathrm{N}$, water-soluble carbohydrate (WSC), NDF, ADF, and ADIN in guinea grass plants at different regrowth intervals before ensiling

\begin{tabular}{|c|c|c|c|c|c|}
\hline \multirow[b]{2}{*}{ Item $^{1}$} & \multicolumn{4}{|c|}{ Regrowth interval (d) } & \multirow[b]{2}{*}{$\mathrm{SE}$} \\
\hline & 35 & 45 & 55 & 65 & \\
\hline LAB (log cfu/g) & 4.35 & 4.56 & 5.16 & 5.55 & 0.15 \\
\hline ENT (log cfu/g) & 6.13 & 5.57 & 5.52 & 5.72 & 0.09 \\
\hline YM (log cfu/g) & 6.10 & 5.73 & 5.80 & 5.64 & 0.21 \\
\hline $\mathrm{DM}(\%)$ & 19.75 & 19.91 & 20.50 & 25.10 & 0.87 \\
\hline $\mathrm{CP}(\%$ of $\mathrm{DM})$ & 8.10 & 7.10 & 7.31 & 5.66 & 0.32 \\
\hline $\mathrm{NH}_{3}-\mathrm{N}(\%$ of total $\mathrm{N})$ & 2.90 & 3.10 & 2.20 & 2.05 & 0.25 \\
\hline WSC ( $\%$ of DM) & 3.75 & 4.68 & 5.12 & 5.85 & 0.31 \\
\hline NDF ( $\%$ of DM) & 55.85 & 60.21 & 62.35 & 64.12 & 0.87 \\
\hline $\mathrm{ADF}(\%$ of $\mathrm{DM})$ & 29.08 & 29.15 & 31.15 & 32.35 & 0.48 \\
\hline ADIN $(\%$ of total $N)$ & 5.78 & 6.51 & 7.01 & 7.45 & 0.23 \\
\hline
\end{tabular}

${ }^{1} \mathrm{LAB}=$ lactic acid bacteria; ENT $=$ enterobacteria; $\mathrm{YM}=$ yeasts and molds.

(Panicum maximum Jacq.), Cai et al. (1998) detected a LAB population of approximately $\leq 3 \mathrm{log} \mathrm{cfu} / \mathrm{g}$ in fresh forage. Pereira et al. (2007) reported an initial population of LAB of $4.92 \mathrm{log} \mathrm{cfu} / \mathrm{g}$ in elephant grass. The DM content and WSC, NDF, ADF, and ADIN concentrations increased with increasing regrowth interval, whereas the levels of $\mathrm{CP}$ and $\mathrm{NH}_{3}-\mathrm{N}$ decreased with increasing regrowth interval.

A DM content of $25 \%$ is recommended by McDonald et al. (1991) as a requirement for minimizing effluent loss in the silo and the preservation of nutrients in silages. This DM content was obtained only in plants harvested at $65 \mathrm{~d}$ of regrowth. These results should be treated with caution because factors such as the physical structure of the forage, compaction, buffering capacity, and indigenous LAB populations can affect fermentation. The increase in DM and fiber levels with increasing maturity was expected. As plants mature, intensification in stem elongation and a progressive decrease in leaf proportion occur. This leads to a reduction in the cell content and nutritional value of the plant with maturity.

Table 2 shows that all isolates were short, gram-positive bacilli that form colonies with round edges. These bacilli were arranged in pairs or short chains (3-4 cells) and showed a negative reaction in the catalase test. Isolates did not grow at $\mathrm{pH} 9.6$ and $6.5 \% \mathrm{NaCl}$; however, all grew colonies at $\mathrm{pH} 7.2$ and $4 \% \mathrm{NaCl}$ at $45^{\circ} \mathrm{C}$. The carbohydrate fermentation profiles of isolates EM1, EM2, EM3, EM4, EM5, and EM6 were identified as Lactobacillus plantarum with $99.9 \%$ similarity (Table 3). Lactobacillus plantarum, predominant in guinea grass, has been previously isolated and characterized as a predominant species in numerous plants. Lin et al. (1992) found that more than $90 \%$ of the total isolated LAB were homofermentative and had $L$. plantarum as the predominant species from the indigenous microflora of corn and alfalfa. In another study, Pereira et al.

Table 2. Morphology and biochemical characteristics of the isolates EM1, EM2, EM3, EM4, EM5, and EM6 from guinea grass plants ${ }^{1}$

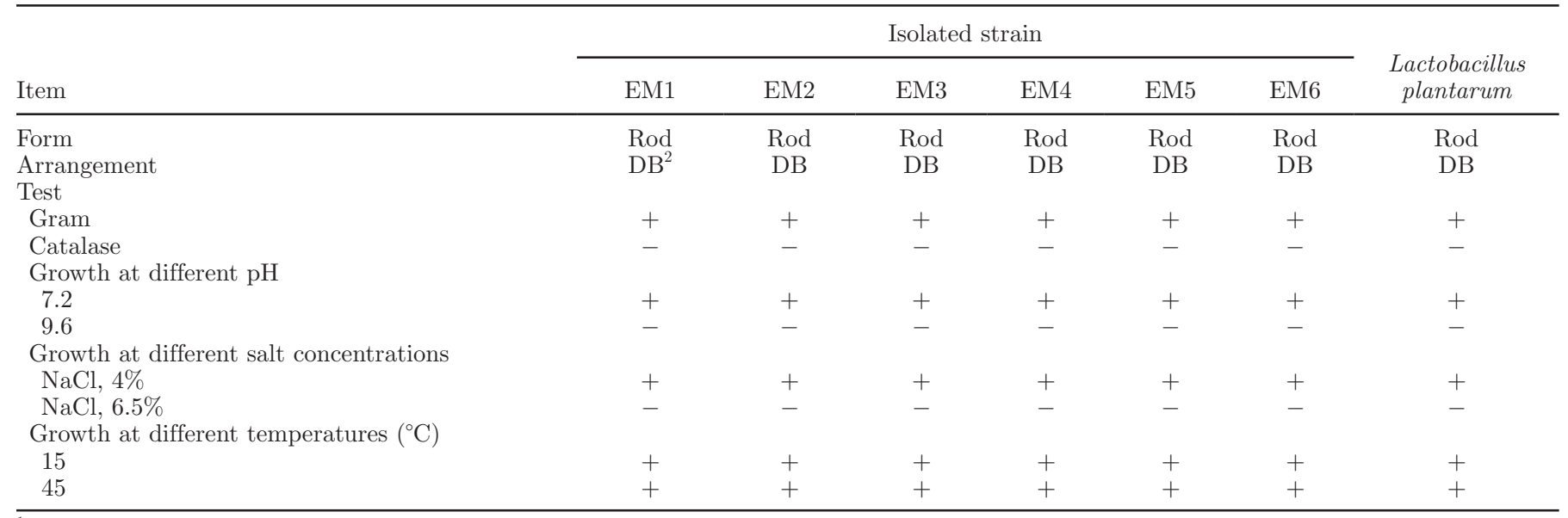

${ }^{1}+=$ positive result; $-=$ negative result.

${ }^{2} \mathrm{DB}=$ diplobacillus. 
Table 3. Carbohydrate fermentation profile of the isolates EM1, EM2, EM3, EM4, EM5, and EM6 from guinea grass plants ${ }^{1}$

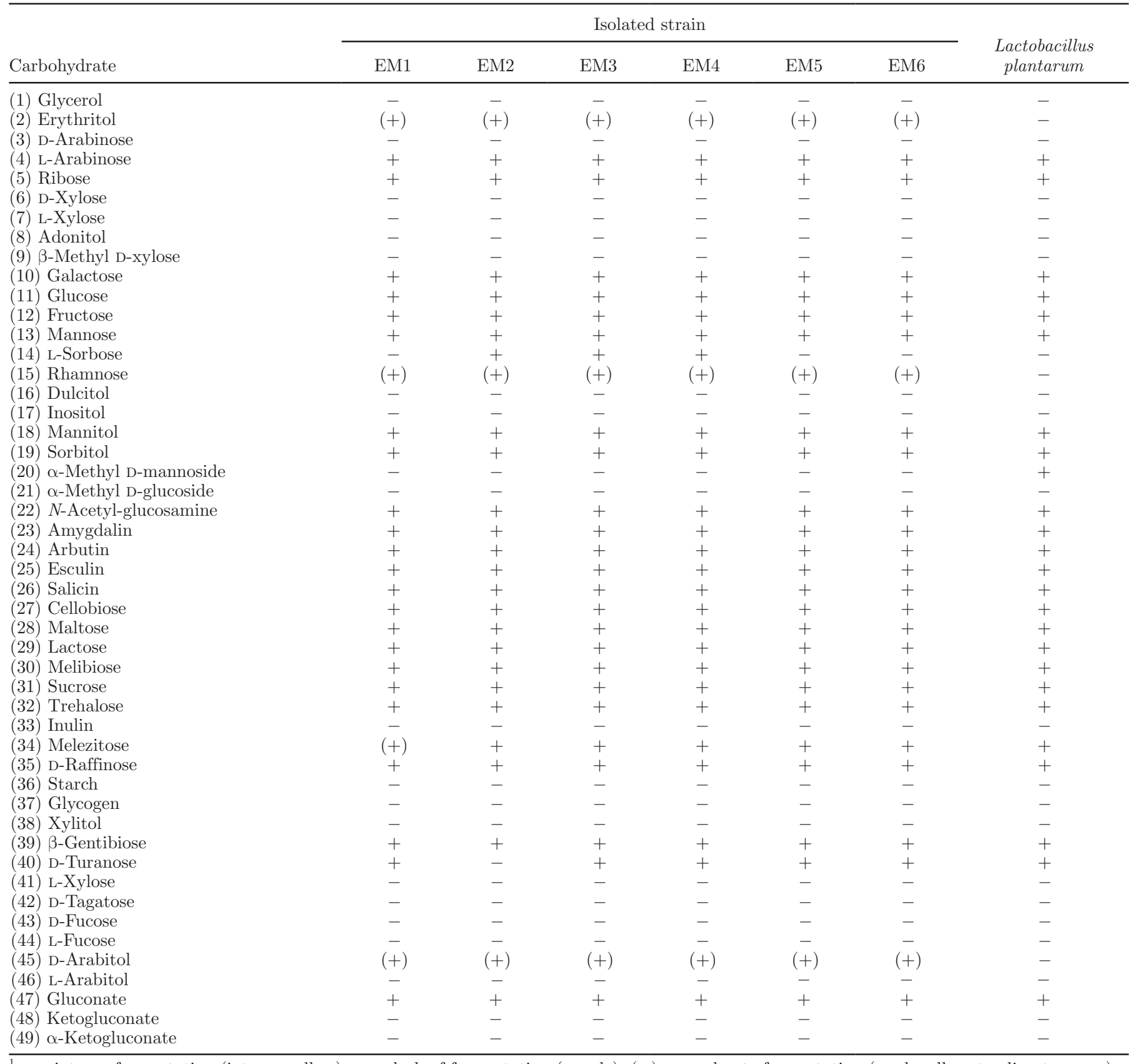

${ }^{1}+=$ intense fermentation (intense yellow); - = lack of fermentation (purple); $(+)=$ moderate fermentation (weak yellow, tending to green).

(2007) assessed the LAB population in elephant grass cultivar Cameroon (Pennisetum purpureum Schum) and identified the isolates as Lactobacillus casei ssp. pseudoplantarum using carbohydrate fermentation profiles as identification criterion. Recently, Lactobacillus fermentum was identified by Rigueira et al. (2013) as the predominant species in plants of signalgrass and guinea grass before ensiling.

The $\mathrm{pH}$ and $\mathrm{NH}_{3}-\mathrm{N}$ values and the levels of lactic, acetic and butyric acids as a function of regrowth in- terval and the use of microbial inoculant are shown in Table 4. The $\mathrm{pH}$ and the concentration of $\mathrm{NH}_{3}-\mathrm{N}$ and lactic and acetic acids were affected by the regrowth interval and inoculant $(P<0.05)$. Butyric acid showed a significant interaction effect $(P<0.05)$. The levels of $\mathrm{NH}_{3}-\mathrm{N}$ decreased linearly $(P<0.05)$ with regrowth interval, whereas the $\mathrm{pH}$ data fit an exponential model.

The use of inoculant reduced the $\mathrm{pH}$ values $(P<$ 0.05 ) at all regrowth intervals. A similar behavior was observed for the $\mathrm{NH}_{3}-\mathrm{N}$ content, except in the silage 
Table 4. Mean values of $\mathrm{pH}, \mathrm{NH}_{3}-\mathrm{N}$, and lactic, acetic, and butyric acids in guinea grass silages as a function of the regrowth interval (RI), inoculant (I), and RI $\times$ I interaction

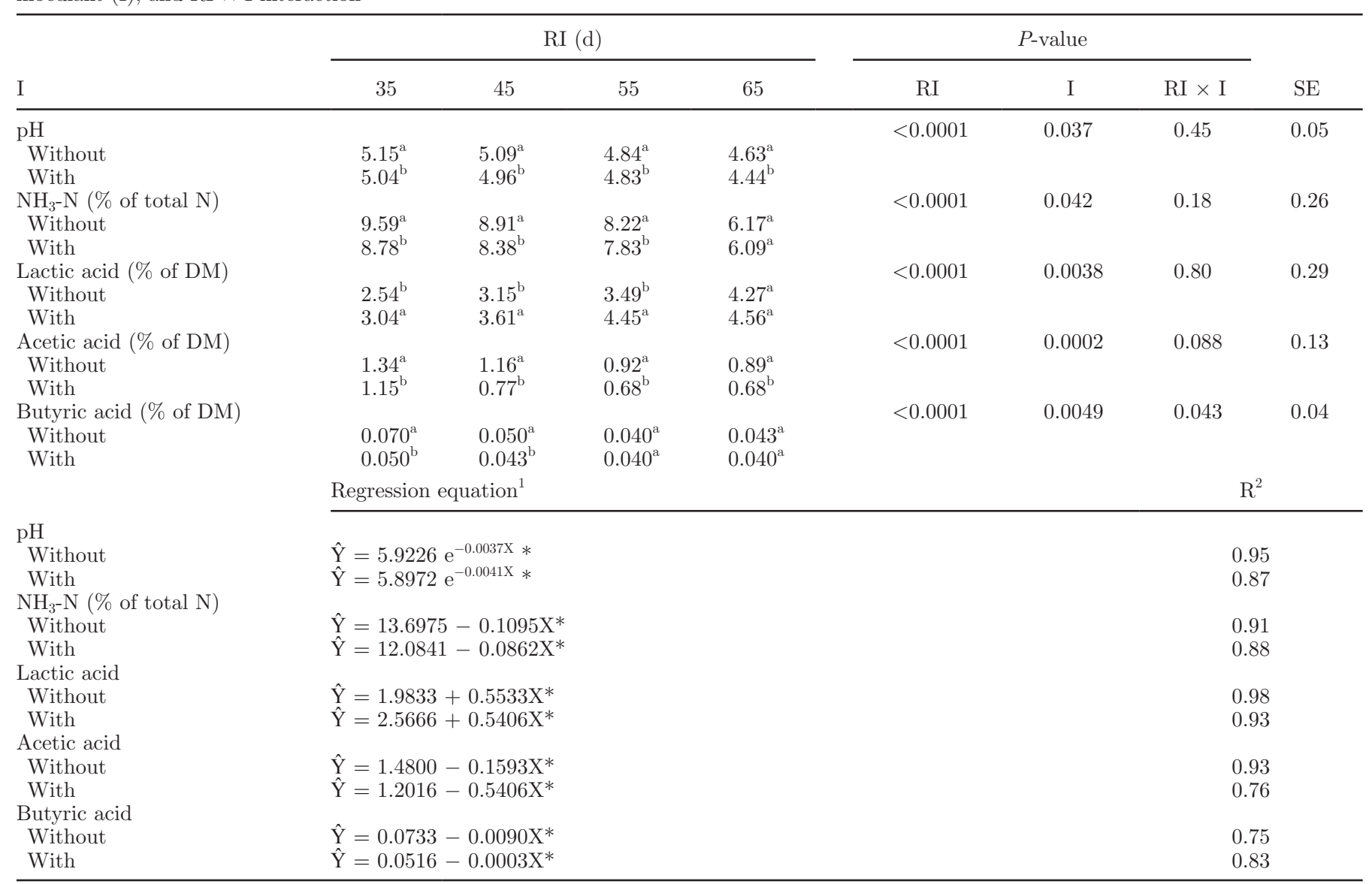

${ }^{\mathrm{a}, \mathrm{b}}$ Within a column, means without a common superscript letter differ $(P<0.05$; Tukey test $)$.

${ }^{1} \hat{Y}=$ estimate of $Y$.

*Significant according to the $t$-test $(P<0.05)$.

of forage harvested at $65 \mathrm{~d}$. The levels of lactic acid increased linearly $(P<0.05)$ with the regrowth interval, whereas the levels of butyric and acetic acids showed a linear decrease $(P<0.05)$. The lactic acid content increased by 0.5533 and 0.5406 units per day of fermentation for silage with and without inoculant, respectively. Higher levels of lactic acid $(P<0.05)$ were found in inoculated silages at all ages, except for forage harvested at $65 \mathrm{~d}$. Inoculation resulted in lower levels $(P<0.05)$ of acetic acid for all regrowth intervals. Higher levels $(P<0.05)$ of butyric acid were observed in silages from forage harvested at 35 and $45 \mathrm{~d}$ without added inoculant.

The higher levels of lactic acid in silages from plants harvested at more advanced regrowth intervals and in the presence of microbial inoculant may be associated with lower $\mathrm{pH}$ values. According to Muck (1996), low $\mathrm{pH}$ values indicate an increase in lactic acid production, leading to a lower production of other organic acids, and a reduction in proteolysis resulting in low $\mathrm{NH}_{3}-\mathrm{N}$ production.

Meeske et al. (1999) observed a reduction in the levels of acetic and butyric acids and increased levels of lactic acid in Digitaria eriantha silage in response to the application of microbial inoculant containing the same species of bacteria present in the inoculant used in this work. However, Rodrigues et al. (2003) and de Andrade and Melotti (2004) found no effect of the microbial inoculant on organic acid levels in elephant grass silage.

Lower $\mathrm{pH}$ and $\mathrm{NH}_{3}-\mathrm{N}$ values in silages of plants harvested at high intervals indicate better fermentation in these silages relative to the silage of younger plants. This effect was most likely due to the higher levels of DM and WSC observed in this work relative to other studies, which promoted a greater production of lactic acid and reduced losses via gas production. Reductions in $\mathrm{pH}$ levels and ammonia production in silages of grass from tropical climates as a function of 
Table 5. Mean values of DM, CP, NDF, ADF, and ADIN in guinea grass silages as a function of the regrowth interval (RI), inoculant (I), and RI $\times$ I interaction

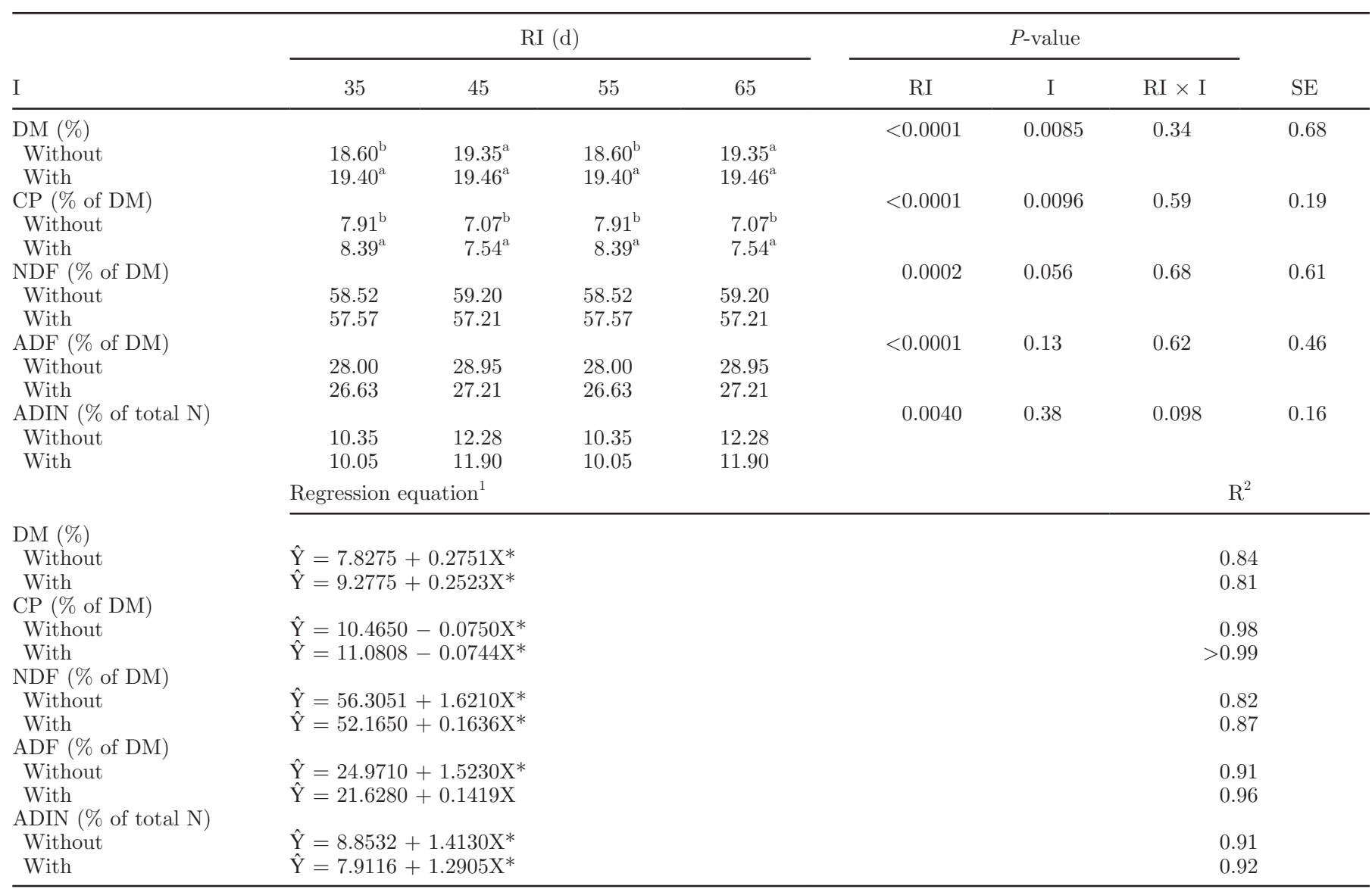

\footnotetext{
${ }^{\mathrm{a}, \mathrm{b}}$ Within a column, means without a common superscript letter differ $(P<0.05$; Tukey test $)$.

${ }^{1} \hat{Y}=$ estimate of $\mathrm{Y}$.

*Significant according to the $t$-test $(P<0.05)$.
}

increasing regrowth interval in silages of signal grass (Brachiaria decumbens) were reported by Santos et al. (2011).

Meeske et al. (1999) also found lower $\mathrm{pH}$ and $\mathrm{NH}_{3}-$ $\mathrm{N}$ levels in silages of Digitaria eriantha treated with microbial inoculant relative to uninoculated controls. Patrizi et al. (2004) evaluated the effects of 3 types of silage inoculant in elephant grass and found that the $\mathrm{pH}$ level was reduced only in inoculants containing Lactobacillus plantarum and Pediococcus acidilactici.

Muck and Kung (1997), in a review article on microbial inoculant studies published between 1990 and 1995, noted that inoculants had been relatively successful in $60 \%$ of the studies, with lower $\mathrm{pH}$ and ammonia nitrogen levels and a predominance of lactic acid and, therefore, a better silage fermentation profile was reported. However, studies of Tanzania grass by Paziani et al. (2006) showed no effect of microbial inoculants on the $\mathrm{pH}$ or ammonia nitrogen levels, or both, in silage. Several factors contribute to the lack of an effect of mi- crobial inoculants on the fermentative profile of silages, including the indigenous LAB population and the WSC and DM contents of the forage.

The mean values of chemical constituents at the different regrowth intervals and with the use of microbial inoculant are shown in Table 5. Effects of the regrowth interval $(P<0.05)$ and inoculant $(P<0.05)$ on the DM and CP levels were detected, whereas the $\mathrm{NDF}, \mathrm{ADF}$, and ADIN concentrations were influenced only by the regrowth interval $(P<0.05)$. Estimated increases in the levels of DM were 0.2751 and 0.2553 units per day of regrowth in silages with and without inoculant, respectively. The $\mathrm{CP}$ content decreased linearly with increasing regrowth interval $(P<0.05)$. The highest levels of CP $(P<0.05)$ in the inoculated silage were recorded in plants harvested at 35,45 , and $55 \mathrm{~d}$ of regrowth. The NDF, ADF, and ADIN concentrations increased linearly $(P<0.05)$ with increasing regrowth interval but were not affected $(P>0.05)$ by the addition of microbial inoculant. 
Table 6. Mean values of the gas and effluent losses and DM recovery (DMR) in guinea grass silages as a function of the regrowth interval (RI), inoculant $(\mathrm{I})$ and $\mathrm{RI} \times \mathrm{I}$ interaction

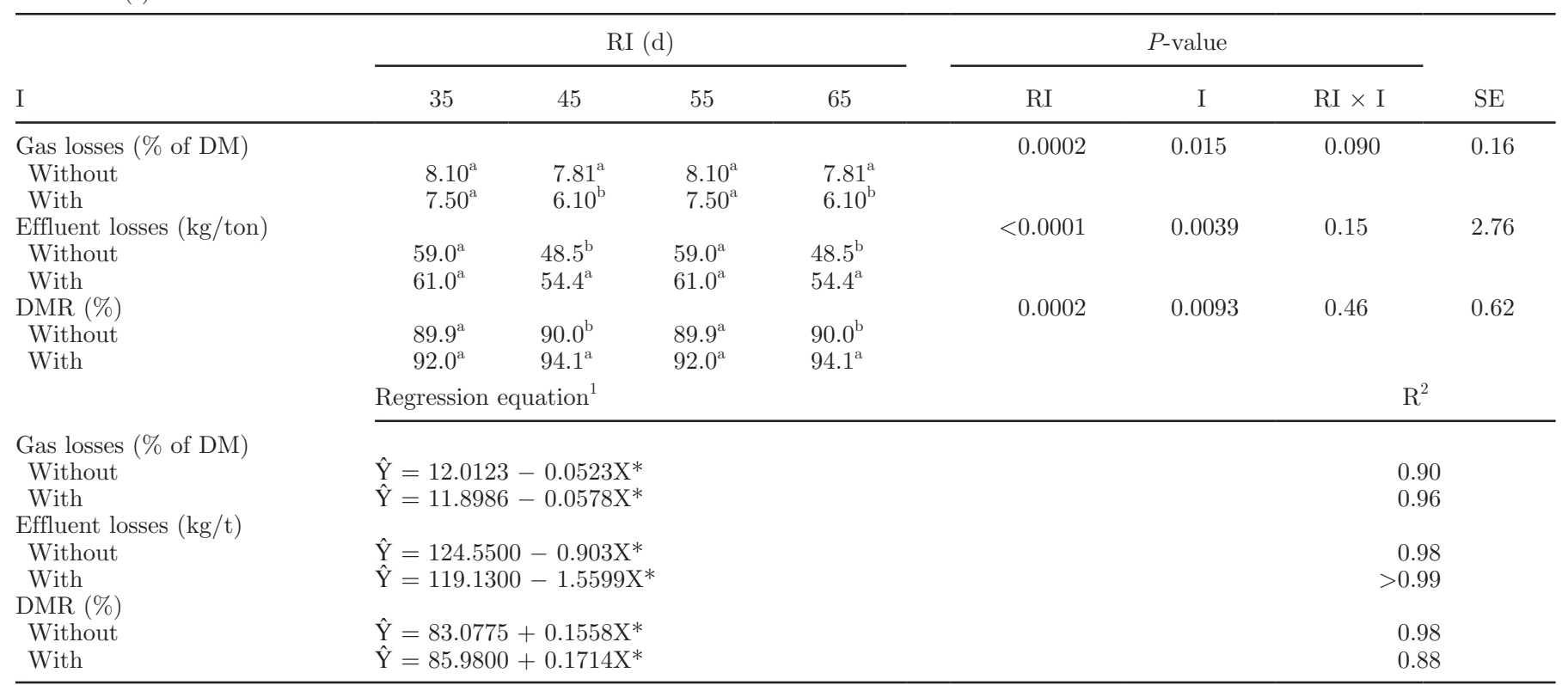

${ }^{\mathrm{a}, \mathrm{b}}$ Within a column, means without a common superscript letter differ $(P<0.05$; Tukey test).

${ }^{1} \hat{Y}=$ estimate of $\mathrm{Y}$.

*Significant according to the $t$-test $(P<0.05)$.

The use of inoculant affected the DM content at the smallest regrowth interval, but no significant differences were found for the other intervals. Penteado et al. (2007) reported increases of 23.1 to $24.8 \%$ in the DM content of inoculated guinea grass silages, whereas Pereira et al. (2007) found no effect of inoculants on these characteristics of elephant grass silage.

The highest observed CP content in inoculated silages may be caused by reduced proteolysis relative to noninoculated silage because a rapid decline in $\mathrm{pH}$ inhibits the development of proteolytic bacteria such as members of the genus Clostridium and enterobacteria (Muck, 1996). Patrizi et al. (2004) also reported higher values of $\mathrm{CP}$ in inoculated elephant grass silage compared with silage without inoculant. In contrast, Meeske et al. (1999), Pereira et al. (2007), and Penteado et al. (2007) did not observe an effect of inoculants on the CP content of the evaluated silages.

An increase in the fiber fraction with increasing regrowth interval was expected based on previous reports. For example, Santos et al. (2011) also reported increases in the levels of NDF, ADF, and ADIN in silages of signal grass at different regrowth intervals. In contrast to the findings of both the Santos et al. (2011) study and the current study, certain authors found that inoculation had an effect on the fiber fraction. Schaefer et al. (1989), working with an inoculant containing Pediococcus acidilactici and Lactobacillus xylosus, reported reductions in the NDF and ADF concentra- tions in corn silage. Similarly, Stokes and Chen (1994) observed a general reduction in the concentration of constituents of the fiber fraction (NDF, ADF, cellulose, and hemicellulose) from 11 to $13 \%$.

Table 6 shows the mean values of the gas loss, effluent loss, and DM recovery as a factor of the microbial inoculation and regrowth interval. All variables were influenced $(P<0.05)$ by the regrowth interval and the inoculant.

Losses through gas production decreased linearly $(P$ $<0.05)$ with increasing regrowth interval, and lower levels of gas production $(P<0.05)$ were observed in inoculated silage for all regrowth intervals. Dry matter recovery increased linearly with increasing regrowth interval $(P<0.05)$; the estimated increase was 0.1714 and 0.1558 units per day of regrowth in inoculated and noninoculated silages, respectively. The highest levels of DM recovery $(P<0.05)$ were observed when the forage was ensiled with inoculant for all regrowth intervals.

A reduction in losses by gas production with increasing regrowth interval may be attributed to the DM levels and higher WSC in plants harvested at more advanced ages. The LAB population, which favors lactic acid fermentation, is also a factor. Gas production in the ensiled mass, according to Muck (1996), is a result of secondary fermentation. Secondary fermentation is performed by enterobacteria, clostridium bacteria, and aerobic microorganisms, which grow optimally at a relatively low DM content. Low levels of WSC result in 
a decreased production of lactic acid and a consequent gradual decrease in the $\mathrm{pH}$, which also favors secondary fermentation.

The linear decrease in the production of effluent in inoculated and noninoculated silages with increasing age of regrowth occurs due to the increased DM level in more mature plants. McDonald et al. (1991) recommend a minimum DM content of $25 \%$ to minimize effluent losses.

One of the uses of microbial inoculants is to foster LAB establishment in the silage and, thus, to reduce losses caused by fermentation reactions. Homofermentative LAB, such as Lactobacillus plantarum, inhibit the development of undesirable microorganisms, reduce losses, and promote a higher recovery of DM. The increases of 0.1558 and 0.1714 units per day of regrowth in DM recovered from silages without and with inoculant, respectively, resulted from the linear decrease in gas and effluent losses in both silages. The highest DM recovery in silages inoculated at different ages reflects their optimal fermentation profile.

\section{CONCLUSIONS}

Based on the morphological and biochemical characteristics and the carbohydrate fermentation profile, Lactobacillus plantarum was found to be the predominant specie of LAB in guinea grass forage. Guinea grass harvested at $55 \mathrm{~d}$ of regrowth, or later, contained a LAB population sufficiently large to ensure good fermentation. The $\mathrm{pH}$ and $\mathrm{NH}_{3}-\mathrm{N}$ values and the organic acid contents of these silages led to higher ensiled DM recovery. The inoculant evaluated in this study increased the recovery of DM and improved the fermentation profile of guinea grass silages at all regrowth intervals.

\section{REFERENCES}

Aganga, A. A., and S. Tshwenyane. 2004. Potentials of guinea grass (Panicum maximum) as a forage crop in livestock production. Pakistan J. Nutr. 3:1-4.

AOAC (Association of Official Analytical Chemists). 1980. Official Methods of Analysis. 13th ed. AOAC, Washington, DC.

Ashbell, G., and Z. G. Weinberg. 2003. Silage from tropical cereals and forage crops. Accessed Mar. 2006. http://www.fao.org/ag/ agp/agpc/gp/silage/htmL/paper7.htm.

Bolsen, K. K., C. Lin, B. E. Brent, A. M. Feyherherm, J. E. Urban, and W. R. Aimutis. 1992. Effect of silage additives on the microbial succession and fermentation process of alfalfa and corn silages. J. Dairy Sci. 75:3066-3083.

Cai, Y., Y. Benno, M. Ogawa, S. Ohmomo, S. Kumai, and T. Nakase. 1998. Influence of Lactobacillus spp. from an inoculant and of Weissella and Leuconostoc spp. from forage crops on silage fermentation. Appl. Environ. Microbiol. 64:2982-2987.

de Andrade, S. J. T., and L. Melotti. 2004. Effect of some additives on the quality of elephant grass (Pennisetum purpureum, Schum) silage. Braz. J. Vet. Res. Anim. Sci. 41:409-415. (In Portuguese with English abstract).
Deriaz, R. E. 1961. Routine analysis of carbohydrates and lignin in herbage. J. Sci. Food Agric. 12:152-160.

Driehuis, F., S. J. W. H. Oude Elferink, and P. G. Van Wikselaar. 2000. Fermentation characteristics and aerobic stability of grass silage inoculated with Lactobacillus buchneri, with or without homofermentative lactic acid bacteria. Grass Forage Sci. 56:330-343.

Evangelista, A. R., J. A. de Lima, and T. F. Bernardes. 2000. Evaluation of some characteristics of star grass (Cynodon nlemfuensis Vanderyst) silage. Rev. Bras. Zootec. 29:941-946. (In Portuguese with English abstract).

FAO (Food and Agriculture Organization of the United Nations). 2009. Panicum maximum Jacq. Grassland Index. A searchable catalogue of grass and forage legumes. Accessed Jan. 6, 2014. http://www. fao.org/ag/AGP/AGPC/doc/GBASE/DATA/PF000278.HTM.

Goering, H. K., and P. J. Van Soest. 1975. Forage Fiber Analyses (Apparatus, Reagents, Procedures, and Some Applications). Agriculture Handbook No. 379. USDA Agricultural Research Service, Washington, DC.

Hack, E. C., A. B. Filho, A. de Moraes, P. C. de Faccio Carvalho, D. Martinichen, and T. N. Pereira. 2007. Structure and milk production in Mombaça grass (Panicum maximum Jacq.) swards submitted to different grazing heights. Ciência Rural 37:218-222. (In Portuguese with English abstract).

Hristov, A. N., and T. A. McAllister. 2002. Effect of inoculants on whole-crop barley silage fermentation and dry matter disappearance in situ. J. Anim. Sci. 80:510-516.

Jobim, C. C., L. G. Nussio, R. A. Reis, and P. Schmidt. 2007. Methodological advances in evaluation of preserved forage quality. Rev. Bras. Zootec. 36:101-119. (In Portuguese with English abstract).

Jobim, C. C., L. L. Sarti, G. T. dos Santos, A. F. Branco, and U. Cecato. 2006. Animal performance and economic return from replacing corn silage by elephant grass silage in Holstein cow diets. Acta Scientiarum Anim. Sci. 28:137-144. (In Portuguese with English abstract).

Licitra, G., T. M. Hernandez, and P. J. Van Soest. 1996. Standardization of procedures for nitrogen fractionation of ruminant feeds. Anim. Feed Sci. Technol. 57:347-358.

Lima, M. L. P., C. G. S. Pedreira, F. A. de Andrade Rosseto, T. T. Berchielli, P. R. Leme, and J. R. Nogueira. 2006. Milk production from crossbred cows in elephant grass and Tanzania guinea grass pastures in Sao Paulo. Boletin de Indústria Animal 63:217-226.

Lin, C., K. K. Bolsen, B. E. Brent, and D. Y. C. Fung. 1992. Epiphytic lactic acid bacteria succession during the pre-ensiling periods of alfalfa and maize. J. Appl. Bacteriol. 73:375-387.

McDonald, P., A. R. Henderson, and S. J. E. Heron. 1991. The Biochemistry of Silage. 2nd ed. Chalcombe Publications, Marlow, UK.

Meeske, R., H. M. Basson, and C. W. Cruywagen. 1999. The effect of a lactic acid bacterial inoculant with enzymes on the fermentation dynamics, intake and digestibility of Digitaria eriantha silage. Anim. Feed Sci. Technol. 81:237-248.

Mertens, D. R. 2002. Gravimetric determination of amylase-treated neutral detergent fiber in feeds with refluxing in beaker or crucibles: Collaborative study. J. AOAC Int. 85:1217-1240.

Muck, R. 1996. Inoculant of silage and its effects on silage quality. Pages 43-52 in Proc. Informational Conf. Dairy Forage Ind. US Dairy Forage Research, Madison, WI.

Muck, R. E., and L. Kung Jr. 1997. Effects of silage additives on ensiling. Pages 187-199 in Proc. Silage: Field to Feedbunk North American Conference. NRAES-99. Northeast Regional Agricultural Engineering Service, Ithaca, NY.

Patrizi, W. L., C. R. F. Madruga Júnior, T. P. Minetto, E. Nogueira, and M. G. Morais. 2004. Effect of commercial biological additives on elephant grass (Pennisetum purpureum Schum.) silage. Arq. Bras. Med. Vet. Zootec. 56:392-397. (In Portuguese with English abstract).

Paziani, S. F., L. G. Nussio, D. R. S. Loures, M. S. Igarasi, A. F. Pedroso, and L. J. Mari. 2006. Effects of dry matter content and bacterial inoculant on the physical and chemical properties and losses in Tanzânia grass silage. Acta Scientiarum Anim. Sci. 28:265-271. (In Portuguese with English abstract). 
Pell, A. N., and P. Schofield. 1993. Computerized monitoring of gas production to measure forage digestion in vitro. J. Dairy Sci. 76:1063-1073.

Penteado, D. C. S., E. M. Santos, G. G. P. de Carvalho, J. S. de Oliveira, A. M. Zanine, O. G. Pereira, and C. L. L. F. Ferreira. 2007. Lactobacillus plantarum from microbiota as inoculant for Panicum maximum silage. Arch. Zootec. 56:191-202. (In Portuguese with English abstract).

Pereira, O. G., K. D. Rocha, and C. L. L. F. Ferreira. 2007. Chemical composition, characterization, and population of microorganisms on elephant grass "Cameroon" (Pennisetum purpureum, Schum) and its silages. Rev. Bras. Zootec. 36:1742-1750. (In Portuguese with English abstract).

Ribeiro, J. L., L. G. Nussio, G. B. Mourão, L. J. Mari, M. Zopollatto, and S. de Fátima Paziani. 2008. Valor nutritivo de silagens de capim-marandu submetidas aos efeitos de umidade, inoculação bacteriana e estação do ano. Rev. Bras. Zootec. 37:1176-1184. (In Portuguese with English abstract).

Rigueira, J. P. S., O. G. Pereira, K. G. Ribeiro, H. C. Mantovani, and M. C. N. Agarussi. 2013. The chemical composition, fermentation profile, and microbial populations in tropical grass silages. Rev. Bras. Zootec. 42:612-621.

Rodrigues, P. H. M., T. F. T. Lopes, S. T. J. de Andrade, L. Melotti, C. de Sousa Lucci, F. R. de Lima, and P. M. Meyer. 2003. Microbial inoculants addition on chemical composition and fermentation characteristics of elephant grass (Pennisetum purpureum, Schum) silage. Acta Scientiarum Anim. Sci. 25:397-402. (In Portuguese with English abstract).

Santos, E. M., O. G. Pereira, R. Garcia, C. L. L. F. Ferreira, J. S. Oliveira, T. C. Silva, and L. O. Rosa. 2011. Microbial populations, fermentative profile and chemical composition of signalgrass silages at different regrowth ages. Rev. Bras. Zootec. 40:747-755.

Santos, E. M., T. C. Silva, C. H. O. Macedo, and F. S. Campos. 2013 Lactic acid bacteria in tropical grass silages. Pages 335-362 in Lactic Acid Bacteria: R\&D for Food, Health and Livestock Purposes. M. Kongo ed. InTech, Rijeka, Croatia.
Santos, E. M., A. M. Zanine, D. J. Ferreira, J. S. Oliveira, D. S. C Penteado, and O. G. Pereira. 2008. Activated inoculant improve Tanzania-grass (Panicum maximum) silage. Arch. Zootec. 57:3542. (Eng. Abstr.)

Schaefer, D. M., P. G. Brotz, S. C. Arp, and D. K. Cook. 1989. Inoculation of corn silage and high-moisture corn with lactic acid bacteria and its effect on the subsequent fermentation and on feedlot performance of beef steers. Anim. Feed Sci. Technol. 25:23-38. (In Portuguese with English abstract).

Schmidt, R. J., and L. Kung Jr. 2010. The effects of Lactobacillus buchneri with or without a homolactic bacterium on the fermentation and aerobic stability of corn silages made at different locations. J. Dairy Sci. 93:1616-1624.

Silva, F. F., M. S. M. A. Aguiar, C. M. Veloso, A. J. V. Pires, P. Bonomo, G. S. Dutra, V. S. Almeida, G. G. P. Carvalho, R. R. Silva, A. M. Dias, and L. C. V. Ítavo. 2006. Performance of dairy heifers fed on elephant grass silage added with different levels of cassava bagasse. Arq. Bras. Med. Vet. Zootec. 58:205-211. (In Portuguese with English abstract).

Snedecor, G. W., and W. G. Cochran. 1980. Statistical Methods. 6th ed. Iowa State Univ. Press, Ames.

Snyman, L. D., and H. W. Joubert. 1996. Effect of maturity stage and method of preservation on the yield and quality of forage sorghum. Anim. Feed Sci. Technol. 57:63-73.

Stokes, M., and J. Chen. 1994. Effect of an enzyme-inoculant mixture on the course of fermentation of corn silage. J. Dairy Sci $77: 3401-3409$.

Universidade Federal de Viçosa. 1999. SAEG - Sistema para Análises Estatísticas, Versão 8.1: Fundação Arthur Bernardes - UFV - Viçosa, 1999. Universidade Federal de Viçosa, Viçosa, Brazil.

Zanine, A. M., E. M. Santos, J. R. R. Dórea, P. A. S. Dantas, T. C. Silva, and O. G. Pereira. 2010. Evaluation of elephant grass silage with the addition of cassava scrapings. Rev. Bras. Zootec. $39: 2611-2616$ 